\title{
Influence Of Organizing Functions, Direction Functions And Planning Functions On Nurse Performance At Hospital Royal Prima Medan
}

\author{
Dennis Wijaya ${ }^{1}$, Ermi Girsang ${ }^{2 *}$, Sri Lestari Ramadhani ${ }^{3}$, Sri Wahyuni Nasution ${ }^{4}$, Ulina Karo Karo ${ }^{5 *}$ \\ 1,2,3,4,5 Master in Public Health, University Proma Indonesia, Medan North Sumatra, Indonesia \\ *Corresponden Author \\ Email: ermigirsang@unprimdn.ac.id
}

\begin{abstract}
The optimal implementation of the managerial function of the head of the room is one of the factors that affect the performance of the team leader and has an impact on the quality of nursing services. Phenomena that occur in hospitals are often the head of the room busy with meeting activities held by hospital management so that the implementation of the role and function of the head of the room as a clinical supervisor who becomes a consultant for team leaders in nursing care is often neglected.The results of the study using product moment analysis found that there was an effect of implementing the managerial function of the head of the room on the performance of the team leader $(p=0.00 r=0.905)$. The results of multiple linear regression showed that only the implementation of the planning function influenced the team leader's performance $(p=0.039 \mathrm{~B}=4.150)$. The conclusion is that the higher the implementation of the planning function carried out by the head of the room, the better the performance of the team leader. The implications for nursing in this research are that it is necessary to improve the ability of the planning function of the head of the room through strategic planning training and developing nursing managerial concepts.
\end{abstract}

Keywords: Team method, managerial function, and performance

\section{INTRODUCTION}

According to the decision of the Minister of Health of the Republic of Indonesia, the service system No. 340/MENKES/PER/III/2010 is a hospital is a health service institution that provides complete individual health services that provide inpatient, outpatient and emergency services. While the definition of a hospital according to the Regulation of the Minister of Environmental Health Hospital, it is stated that: A hospital is a health service facility, a gathering place for sick and healthy people, or can be a place for disease transmission and allows environmental pollution and health problems (Ministry of Health RI).Performance is the result of work that can be achieved by a person or group of people in an organization in accordance with their respective authorities and responsibilities in order to achieve organizational goals (Prawirosentono, 2014) within a certain period of time.

And there is a close relationship between individual performance and organizational performance, in other words, if employee performance is good, it is likely that organizational performance is also good. Performance is also translated as a description of the level of achievement of the implementation of an activity/program/policy in realizing the goals, objectives, mission and vision of the organization contained in the strategic planning of an organization (Mohamad Mahsun, 2013).According to Allen (2012:146), says that: Job involvement will increase if members in the organization face a situation that is important to discuss together. One of the situations that need to be discussed together, for example, is the personal needs and interests that members want to achieve. If these needs can be met, it will make members more committed to the organization.From the results of the evaluation of the application of nursing care standards at the Royal Prima Hospital, Medan. Based on the initial data obtained, it shows that the application of nursing care standards in the form of nursing assessments, nursing diagnoses, planning, nursing actions / implementation and evaluation is shown in table 1.1 as follows: 
Table 1. Results of the Implementation of Nursing Care Standards at Royal Prima Madan Hospital

\begin{tabular}{|l|l|l|l|}
\hline No\% & Rated aspect & Achievements (\%) & Standard \\
\hline 1 & Nursing Assessment & 44.44 & 100 \\
\hline 2 & Nursing Diagnosis & 33.33 & 100 \\
\hline 3 & Nursing Planning & 11.11 & 100 \\
\hline 4 & Nursing actions & 33.33 & 100 \\
\hline 5 & Nursing Evaluation & 33.33 & 100 \\
\hline 6 & Nursing Care Notes & 22.22 & 100 \\
\hline
\end{tabular}

Source: part of the nursing committee of the Royal Prima Hospital in Medan

From these data, the results show that in all aspects assessed and the average achievement is still below the standard 100\% accuracy of Royal Prima Hospital Medan. So the problem of implementing nursing care standards is still low. To be able to implement the performance of nursing management in the inpatient room, it is necessary to have a head of the room who meets managerial standards. The managerial ability of the head of the inpatient room is expected to have a minimum education level of S1 in nursing, at the Royal Prima Hospital Medan by $91.7 \%$ or 11 inpatient rooms the head of the room has a Bachelor of Nursing. For the head of the nursing education team, there were 9 people (23\%) and 30 people (77\%) with DIII nursing education. Based on a preliminary study at the Royal Prima Hospital, Medan, what people often complain about is the slow service provided by nurses. Based on the results of interviews and observations of the head of the room and the nurse implementing the management function in the room is still not good, nurses work as they are. Low respect for nurses,

\section{LITERATURE REVIEW.}

\subsection{Nursing Managerial Role}

The head of the room and the room supervisor play a very important role in motivating the implementing nurses with careful planning and correct direction to the implementing nurses (Nivalinda, 2013). The head of the room has ten roles which are then grouped into three roles. The role of the head of the room in question is the role of interpersonal relationships, the role of information, and the role of decisions (Robbins, 2015). Supervisors also have an important role in carrying out their duties. The supervisor's role is as a mentor, power perspective, and networking (Sitorus \& Panjaitan, 2011)

\subsection{The managerial role consists of:}

1. Interpersonal Role In the interpersonal role there are three leadership roles that arise directly from the formal authority of the leader and include basic interpersonal relationships, namely:

a. Figurehead Role Because of his position as the leader of an organizational unit, the leader must carry out ceremonial tasks such as welcoming important guests, attending the wedding of his subordinates, or hosting lunches for customers or colleagues. Activities related to interpersonal roles are often routine, without important communication or decisions.

b. Role as a leader (Leader Role) A leader is responsible for the work of the people in the organizational unit he leads. Activities related to it relate to leadership directly and indirectly. Those directly related to leadership include the recruitment and training of its staff. Meanwhile, indirectly related, among others, a leader must motivate and encourage his subordinates.

c. Liaison Role Management literature has always recognized the role of a leader, especially aspects related to motivation. Only recentlyrecognition of the liaison role, in which the leader establishes contacts outside the vertical chain of command, is beginning to emerge.

2. Informational Role Due to his interpersonal contacts, both with subordinates and with other contact networks, a leader emerges as the nerve center for his organizational unit. Leaders may not know everything, but at least they know more than their staff. Information processing is a key part of a leader's job. The following three leadership roles describe the informational aspect. 
a. Monitor Role As a monitor, a leader continuously monitors his environment for information, he also frequently has to 'interrogate' his contacts and subordinates, and sometimes receives free information, mostly the result of the network of personal contacts he has developed.

b. Disseminator role Most of the information obtained by the leader must be shared and distributed to subordinates in need. In addition, when his subordinates cannot contact each other easily, it is the leader who sometimes has to pass information from one subordinate to another.

c. Role as spokesperson (Spokesman Role) As a spokesman, a leader has the right to convey information he has to people outside his organizational unit.

3. The Role of Decision Making (Decisional Role) Information obtained by the leader is not the ultimate goal, but is the basic input for decision making. According to his formal authority, only the leader can set his organizational commitment in a new direction; and as the nerve center of the organization, only he has the correct and comprehensive information that can be used to decide the strategy of the organization. In relation to the leader's role as a decision maker, there are four leadership roles, namely:

a. Role as an entrepreneur (Entrepreneur Role) As an entrepreneur, a leader must strive to always improve the performance of his unit and adapt to changes in the environment in which the organization exists.

b. The role as a disturbance handler (Disturbance handler Role) The role as a disturbance controller reflects the leader's need to respond to the pressures faced by his organization. Here change is something beyond the control of the leader. He had to act because the pressure of the situation was so strong that it couldn't be ignored. Leaders often have to spend most of their time responding to stressful distractions. No organization functions so seamlessly, so standardized, that it takes into account all the uncertainties of the environment from the start

c. Role as allocator of resources (Resource allocator Role) In the leader lies the responsibility to decide who will receive what in his organizational unit. Perhaps the most important resource a leader allocates is time.

d. Role as a negotiator (Negotiator Role) Many studies on managerial work indicate that leaders spend quite a lot of time in negotiations. As stated by Leonard Sayles, negotiation is the way of life of a sophisticated leader. Negotiation is a leader's duty, it may be routine, but it should not be avoided

\subsection{Definition of Performance}

Performance is the result of work that can be achieved by a person or group of people in an organization in accordance with their respective authorities and responsibilities in order to achieve organizational goals (Prawirosentono, 2014) within a certain period of time. And there is a close relationship between individual performance and organizational performance, in other words, if employee performance is good, it is likely that organizational performance is also good. Performance is also translated as a description of the level of achievement of the implementation of an activity/program/policy in realizing the goals, objectives, mission and vision of the organization contained in the strategic planning of an organization (Mohamad Mahsun, 2013). The standard set by the Indonesian Ministry of Health regarding the implementation of nursing care documentation is $75 \%$. Documentation of poor care can be associated with many variables, including work motivation, work stress, workload, leadership style, less harmonious human relations, ineffective supervision from superiors, and possible work saturation (Supratman \& Utami, 2009). As for the impact if the role of the head of the room is not carried out properly, there will be a decrease in health services, a decrease in employee motivation, a decrease in employee skills or abilities, lack of employee discipline, lack of actual and updated information from outside or within the organization, disorganized existing resources, and there is difficulty in problem solving (Robbins, 2015). The impact if the supervisor's role is not carried out properly is that the relationship in carrying out the nursing process will be weak, decrease employee motivation and decrease employee commitment to the quality of health services (Sitorus \& Panjaitan, 2011). 


\section{RESEARCH METHODS}

\subsection{Types of Research}

This type of research is a research using a cross sectional study design which is one of the analytical research designs and belongs to the type of observational research. This design aims to see the effect of managerial functions on the performance of nurses in carrying out nursing care at the Royal Prima Hospital in Medan. A cross-sectional approach is used because the measurement of managerial functions (independent variables) is carried out together to see whether or not there is an effect between the two (Sastroasmoro, 2016).

\subsection{Population and Research Sample}

\subsubsection{Population}

The population is a generalization area consisting of objects or subjects that have certain qualities and characteristics determined by the researcher, then conclusions are drawn (Sugiono, 2006). The population of this study were 280 nurses at the Royal Prima Hospital in Medan.

\subsubsection{Sample}

The sample is part of the number and characteristics possessed by the population (Sugiono, 2006). This research was conducted by sampling technique using a total sampling of 280 nurses.

\subsection{Validity Test}

Validity test is used to measure the validity or invalidity of a questionnaire. The questionnaire is valid if the questions on the questionnaire or reveal something that will be measured by the questionnaire.Test the validity of the questionnaire to see the accuracy of the measuring instrument measuring the variable being measured. Before carrying out the validity test, a search for the correlation value between the parts of the measuring instrument will be carried out by correlating each measuring instrument item with the total score which is the number of item scores, while the reliability test to see the level of consistency of the instrument is carried out using the formulaCronbach's Alpha. The instrument is said to be reliable if the result alpha $>0.60$. Based on the table above, it is known that the coefficient value with reliability interpretation is above 0.60 . This shows that the reliability is quite good.

\section{RESULTS AND DISCUSSION}

The variable in this study is the Managerial Function as an independent variable and consists of four functions and individual performance as measured by the ability to carry out nursing care as the dependent variable. The following discusses the four managerial functions and individual performance of nurses in carrying out nursing care.

\subsubsection{Organizing Function}

Table 2. Distribution of Answers About Organizing Functions at Royal Prima Hospital Medan in 2021

\begin{tabular}{|c|c|c|c|c|c|c|c|c|c|c|c|}
\hline No & Statement & TS & $\%$ & $\mathrm{KS}$ & $\%$ & $\mathrm{~S}$ & $\%$ & $\mathrm{SS}$ & $\%$ & $\square$ & $\%$ \\
\hline 1 & $\begin{array}{l}\text { Make details of katim } \\
\text { tasks and team members }\end{array}$ & 0 & 0 & 1 & 6.7 & 9 & 60.0 & 5 & 33.3 & 15 & 100 \\
\hline 2 & $\begin{array}{l}\text { Create spans of control for } \\
\text { karu, katim and members }\end{array}$ & 9 & 60.0 & 2 & 13.3 & 4 & 26.7 & 0 & 0 & 15 & 100 \\
\hline 3 & $\begin{array}{l}\text { Organize and control } \\
\text { nursing staff }\end{array}$ & 0 & 0 & 0 & 0 & 10 & 66.7 & 5 & 33.3 & 15 & 100 \\
\hline 4 & Delegate nursing duties & 0 & 0 & 1 & 6.7 & 9 & 60.0 & 5 & 33.3 & 15 & 100 \\
\hline 5 & $\begin{array}{l}\text { Giving authority to TU } \\
\text { staff }\end{array}$ & 0 & 0 & 1 & 6.7 & 7 & 46.7 & 7 & 46.7 & 15 & 100 \\
\hline
\end{tabular}

In table .2. it can be seen the distribution of answers about the function of the details of the tasks of the katim and team members there are 9 respondents who answered agree (60.0\%), and disagree with making a span of control for karu, katim and members there were 9 respondents $(60.0 \%)$, managing and controlling nursing staff there are 10 respondents who answered agree $(66.7 \%)$, the delegation of nursing tasks there were 9 
respondents who answered less agree $(60.0 \%)$ and agreed to give authority to the TU staff there were 7 respondents $(46.7 \%)$.

\subsubsection{Briefing Function}

Tables 3. Distribution of Answers About the Briefing Function at Royal Prima Hospital Medan in 2021

\begin{tabular}{|c|c|c|c|c|c|c|c|c|c|c|c|}
\hline No & Statement & TS & $\%$ & $\mathrm{KS}$ & $\%$ & $\mathrm{~S}$ & $\%$ & SS & $\%$ & $\square$ & $\%$ \\
\hline 1 & Give feedback & 0 & 0 & 1 & 6.7 & 4 & 26.7 & 10 & 66.7 & 15 & 100 \\
\hline 2 & Inform important things & 0 & 0 & 0 & 0 & 8 & 53.3 & 7 & 46.7 & 15 & 100 \\
\hline 3 & $\begin{array}{l}\text { Does not provide } \\
\text { motivation in improving } \\
\text { health care }\end{array}$ & 8 & 53.3 & 7 & 46.7 & 0 & 0 & 0 & 0 & 15 & 100 \\
\hline 4 & $\begin{array}{l}\text { Giving praise to nurses in } \\
\text { health care }\end{array}$ & 0 & 0 & 0 & 0 & 5 & 33.3 & 8 & 53.3 & 15 & 100 \\
\hline 5 & $\begin{array}{l}\text { Not Guiding Nurses in } \\
\text { Askep Correctly }\end{array}$ & 2 & 13.3 & 13 & 86.7 & 0 & 0 & 0 & 0 & 15 & 100 \\
\hline 6 & $\begin{array}{l}\text { Doesn't Improve } \\
\text { collaboration with team } \\
\text { members }\end{array}$ & 0 & 0 & 0 & 0 & 5 & 33.3 & 9 & 64.3 & 15 & 100 \\
\hline
\end{tabular}

In table 4.3. it can be seen the distribution of answers about the function of directing the head of the room that does not provide motivation in improving nursing care there are 8 respondents who answered disagree (53.3\%) gave praise to nurses in health care there were 8 respondents who answered strongly agree (53.3\%) and did not Guiding nurses in health care correctly there were 13 respondents who answered that they did not agree $(86.7 \%)$.

\subsubsection{Oversight function}

Table 4. Distribution of Answers About Supervision Functions at Royal Prima Hospital Medan in 2021

\begin{tabular}{|c|c|c|c|c|c|c|c|c|c|c|c|}
\hline No & Statement & $\mathrm{TS}$ & $\%$ & $\mathrm{KS}$ & $\%$ & $\mathrm{~S}$ & $\%$ & SS & $\%$ & $\square$ & $\%$ \\
\hline 1 & $\begin{array}{l}\text { Communicating } \\
\text { supervision }\end{array}$ & 0 & 0 & 0 & 0 & 9 & 60.0 & 6 & 40.0 & 15 & 100 \\
\hline 2 & $\begin{array}{l}\text { Perform routine } \\
\text { document checks }\end{array}$ & 0 & 0 & 0 & 0 & 7 & 46.7 & 8 & 53.3 & 15 & 100 \\
\hline 3 & Check attendance list & 0 & 0 & 0 & 0 & 10 & 66.7 & 5 & 33.3 & 15 & 100 \\
\hline 4 & $\begin{array}{l}\text { During supervision, pay } \\
\text { attention to the progress } \\
\text { and quality of health care }\end{array}$ & 0 & 0 & 2 & 13.3 & 10 & 66.7 & 3 & 20.0 & 15 & 100 \\
\hline 5 & $\begin{array}{l}\text { Not Involved in the } \\
\text { repair of Askeps during } \\
\text { supervision }\end{array}$ & 5 & 33.3 & 10 & 66.7 & 0 & 0 & 0 & 0 & 15 & 100 \\
\hline 6 & $\begin{array}{l}\text { Assessing the knowledge } \\
\text { and skills of nurses in } \\
\text { health care }\end{array}$ & 0 & 0 & 1 & 6.7 & 10 & 66.7 & 4 & 26.7 & 15 & 100 \\
\hline 7 & $\begin{array}{l}\text { Evaluating the nurse's } \\
\text { appearance }\end{array}$ & 4 & 26.7 & 10 & 66.7 & 1 & 6.7 & 0 & 0 & 15 & 100 \\
\hline
\end{tabular}

In table 4. it can be seen the distribution of answers about the direct supervision function there are 6 respondents who answered strongly agree (40.0\%), when supervision paid attention to the progress and quality of health care there were 5 respondents who answered agree $(33.3 \%)$, not involved in improving health care during supervision there were 5 respondents who answered disagreed (33.3\%), assessed the knowledge and skills of nurses in health care services there were 10 respondents who answered agree $(66.7 \%)$ and evaluated the appearance of nurses there were 4 respondents who answered disagreed $(26.7 \%)$.

\subsection{The Influence between Independent Variables (Managerial Functions) and Dependent Variables (Individual Performance)}

a. $\quad$ Influence of Planning Function with Individual Performance

To determine the effect between the planning function of the head of the room with the individual performance of nurses in the implementation of health care services, it can be seen in the following table: 
Table 5. The results of the influence between the planning function of the head of the room with the individual performance of the head nurse and the performance of individual nurses in the implementation of health care services at the Royal Prima Hospital Medan, 2021

\begin{tabular}{lllllllll}
\hline Planning function & \multicolumn{9}{l}{ Total Performance } & & & & \\
\cline { 2 - 8 } & $\mathrm{N}$ & $\%$ & $\mathrm{~N}$ & $\%$ & $\mathrm{~N}$ & $\%$ & $\mathrm{p}$ & $\mathrm{X} 2$ \\
\hline Good & 7 & 53.8 & 6 & 46.2 & 13 & 100 & 0.919 & 0.10 \\
Not good & 1 & 50.0 & 1 & 50.0 & 2 & 100 & & \\
Total & 8 & 53.3 & 7 & 46.7 & 15 & 100 & & \\
\hline
\end{tabular}

Based on the table, it can be seen that all respondents answered that the planning function variable had an effect on individual performance at the Royal Prima Hospital Medan in the bad category (50.0\%) and the minority was in the good category (53.8\%). Meanwhile, the majority of individual performance is not good $(50.0 \%)$ and the minority is good $(46.2 \%)$.

on the results of this bivariate analysis using the Chi-square test, the obtained value of $\mathrm{X} 2=0.10, \mathrm{p}$ value $=0.919, \mathrm{p}>0.05$, which means that there is no significant or significant effect between the planning function and individual performance.

The cross tabulation shows that the planning function of the head of the ward will affect the individual performance of the nurse, compared to the planning function of the head of the ward which is not good, will affect the performance of the individual to be not good. The function of service planning and health care services in the Inpatient Room carried out by the head of the room is the thoughts or concepts of a manager's written actions (Dwi Ida, 2017). Planning is defined as the details of activities about what must be done, how activities are carried out and how the activities are carried outwhere the activity takes place. Planning for the head of the room includes annual, monthly, weekly and daily planning. Besides that, the planning of staff requirements and the method of assignment must be clear and provide guidelines for implementing nurses.

b. $\quad$ The Influence of Organizing Functions with Individual Performance

To determine the effect of the organizing function of the head of the room with the performance of individual nurses in the implementation of nursing care can be seen in the following table:

Table 6. The results of the influence between the organizing function of the head of the room and the performance of individual nurses in the implementation of health care services at the Royal Prima Hospital Medan, 2021

\begin{tabular}{lllllllll}
\hline Organizing function & \multicolumn{9}{l}{ PerformanceTotal } & \multicolumn{1}{l}{} & \\
\cline { 2 - 8 } & $\mathrm{n}$ & $\%$ & $\mathrm{n}$ & $\%$ & $\mathrm{n}$ & $\%$ & $\mathrm{p}$ & $\mathrm{X} 2$ \\
\hline Good & 1 & 16.7 & 5 & 83.3 & 6 & 100 & 0.020 & 5,402 \\
Not good & 7 & 77.8 & 2 & 22.2 & 9 & 100 & & \\
Total & 8 & 53.3 & 7 & 46.7 & 15 & 100 & & \\
\hline
\end{tabular}

Based on the table, it can be seen that all respondents answered that the organizational function variable affects individual performance at the Royal Prima Hospital Medan with the bad category (77.8\%) and the minority being in the good category $(16.7 \%)$. Meanwhile, the performance of the majority of individuals is not good $(22.2 \%)$ and the minority is $\operatorname{good}(83.3 \%)$.

on the results of this bivariate analysis using the Chi-square test, the obtained value of $\mathrm{X} 2=5.402, \mathrm{p}$ value $=0.020, \mathrm{p}<0.05$, which means that there is a significant or significant effect between the organizing function and individual performance.

Managerial ability in the organizing function is expected to help implementing nurses to carry out health care performance to clients properly and correctly. Organizing is the overall grouping of people, tools, tasks, authorities and responsibilities so as to create an organization that can be moved as a unit in order to achieve the goals that have been set (Dwi Ida, 2017). The organizing principles are division of labor, unity of command, span of control, delegation and coordination. 
c. The Influence of the Directing Function on Individual Performance.

To determine the effect of the organizing function of the head of the room with the performance of individual nurses in the implementation of nursing care can be seen in the following table:

\subsection{Multivariate Analysis}

From the results of multivariate analysis, it can be seen that the independent variable that has the most dominant influence on managerial functions is the directive function variable with $p$ value $=0.563>0.05$ with Exp $B$ value $=0.303$, the organizing function variable with $p$ value $=0.091>0.05$ with the value of $\operatorname{Exp} B=$ 17.075 and for the supervisory function with a value of $p$ value $=0.146>0.05$ with a value of $\operatorname{Exp} B=0.102$. This shows that the organizing function has a 17.075 times greater influence on individual performancenurses in carrying out nursing care at the Royal Prima Hospital Medan. The results of this study are not in line with the research of Semuel (2013) that there is no relationship between the management functions of the head of the room, namely planning, organizing, directing and supervising the performance of implementing nurses.

\section{CONCLUSIONS}

Based on the results of research on the effect of the managerial function of the head of the room on the individual performance of nurses in carrying out nursing care at the Royal Prima Hospital Medan in 2021, the following conclusions can be drawn:

1. There is a significant influence between the organizing function on the performance of nurses in carrying out health care services at the Royal Prima Hospital Medan in 2021.

2. There is no significant effect between the directive function on the performance of nurses in carrying out health care services at the Royal Prima Hospital, Medan in 2021.

3. There is a significant influence between the supervisory function of the head of the room on the individual performance of nurses in implementing health care services at the Royal Prima Hospital Medan in 2021.

\section{REFERENCES.}

[1] Alidon, A. (2019). The Influence of Implementing Nurses' Perceptions About the Managerial Functions of the Head of the Room on the Implementation of Nursing Care Management. Medical Mask, 7(2), 456-466.

[2] Aulia, R., \& Sasmita, J. (2014). The Effect of Education and Training on Job Satisfaction and Leadership on the Performance of Inpatient Nurses in Siak District Hospital.

[3] Amalia, E., Herawati, L., \& Nofiadi, N. (2018, August). The Completeness of Nursing Documentation Factors in the Inpatient Installation of Lubuk Attitude Hospital. In the proceedings of the pioneering health seminar(vol. 1, no. 1).

[4] Ginting, CA (2019). Optimizing Nurse Performance in Implementing Nursing Care.

[5] Handoko, HT Management. Erlangga: 2012.

[6] Hannani, A., \& Ilyas, GB (2016). The Effect of Workload, Satisfaction, and Facilities on the Performance of Nurses in the Mawar Care Room, Second Floor, Rsu Wisata Uit Makassar. Postgraduate Program, AMKOP Makassar College of Economics. Mirai Management Journal, 1(2)

[7] Haryanti, T., Pujianto, TI, \& Adinatha, NN (2013). Analysis of the Influence of Implementing Nurses' Perceptions About Managerial Functions of the Head of Room on Documentation of Nursing Care in Inpatient Rooms at Private Hospitals in Semarang. Journal of Nursing Management, 1(2).

[8] Hrp, ER (2019). The Purpose Of Nursing Care Planning In Improving Maximum Service Outcomes.

[9] Hutagalung, DN (2019). Nursing Care Planning Stages.

[10] Jabbar, SI, Tamsah, H., \& Betan, AB (2017). Analysis of Factors Affecting Nurse Performance at Prof. Hospital. Dr. Hm Anwar Makkatutu, Bantaeng Regency. Journal of Mirai Management, 2(2), 423-432.

[11] Jakri, Y., \& Timun, H. (2019). The Relationship between the Functions of the Head of the Room Management and the Performance of Nurses in Implementing Nursing Care in the Inpatient Room of the Waelengga Health Center, East Manggarai Regency in 2019. Health Insights, 4(2), 56-66. 
[12] Julianto, M., \& Soelarto, RSUP (2016). The Role and Function of Nursing Management in Conflict Management. Fatmawati Hospital Journal.

[13] Muliana, M., Suleman, AR, Arif, NF, Simatupang, S., Sitepu, CNB, Wahyuddin, W., ... \& Purba, S. (2020). Introduction to Management. Our Writing Foundation.

[14] Nasution, EH, \& Musnadi, S. (2018). Factors Affecting Job Satisfaction and Its Impact on the Performance of Regional Office Employees of the Directorate General of Aceh's State Assets. Journal of Masters in Management, 2(1), 123-134.

[15] Passya, P., Rizany, I., \& Setiawan, H. (2019). The Relationship between the Role of the Head of the Room and the Nursing Supervisor with the Motivation of Nurses in Doing Nursing Documentation. Raflesia Journal of Nursing, 1(2), 99-108.

[16] Setyabudi Indartono, Ph.D (2015). Introduction to Character Inside Management. Faculty of Economics, Yogyakarta State University.

[17] Silaban, G., Lubis, AM, \& Salmah, U. (2017). Design of Competency-Based Performance Assessment System for Emergency Nurses at RSU Herna Medan. Andalas Public Health Journal, 10(1), 59-64.

[18] Simanullang, MV (2019). Benefits of the Nursing Process in Providing Nursing Services.

[19] Sitanggang, R. (2019). The Function of Nurses in Enforcing the Application of K3 in Hospitals.

[20] Soepono, DN, \& Srimulyani, VA (2015). Analysis of the Effect of The Big Five Personality on Organizational Citizenship Behavior (OCB) and Nurse Performance at Santa Clara Hospital Madiun. Indonesian Journal of Management, 15(1), 51-64.

[21] Sri Mugianti, (2016). Management and Leadership in Nursing Practice

[22] RI Law No. 340 of 2010 concerning Hospitals

[23] RI Law No. 38 of 2014 concerning Health

[24] Yanti, RI, \& Warsito, BE (2013). The Relationship between Nurse Characteristics, Motivation, and Supervision with the Quality of Nursing Care Documentation. Journal of Nursing Management, 1(2). 